\title{
Analisis Pengaruh Lingkungan Kerja Terhadap Kinerja Pegawai Bank Riau Kepri Syariah Pekanbaru
}

\author{
Wenny Desty Febrian ${ }^{1}$ Zulhaida $^{2}$ \& Abdiana Ilosa ${ }^{3}$ \\ 1,2,3 Fakultas Ekonomi dan Ilmu Sosial \\ Universitas Islam Negeri Sultan Syarif Kasim Riau \\ Jl. HR. Soebrantas Panam KM 15 No.155 Tampan Pekanbaru, 28293 \\ e-mail : wenny.sani27@gmail.com; ida_puanri@yahoo.co.id; ella.abdiana@yahoo.com.
}

\begin{abstract}
Abstrak: Suatu kondisi lingkungan kerja dikatakan baik atau sesuai apabila manusia dapat melaksanakan kegiatan secara optimal, sehat, aman dan nyaman. Kesesuaian lingkungan kerja dapat dilihat akibatnya dalam jangka waktu panjang yang lama. Lingkungan kerja yang kurang baik atau boleh dikatakan buruk akan mempengaruhi mental dan psikis seseorang. Dalam hal ini sumber daya manusianya yang akan menyebabkan turunnya kinerja pegawai yang tentunya akan merugikan instansi/perusahaan. Pada Bank Riau Kepri Syariah terdapat pegawai tetap dan tidak tetap adalah 35 orang dengan latar belakang S2 , S1, SMA, SLTP yang bertugas berbeda-beda. Dari hasil pengamatan penulis, lingkungan kerja pada Bank Riau Kepri Syariah Pekanbaru dapat dilihat dari ruangan kerja yang bersih dan nyaman , kerja sama antara pegawai serta fasilitas kantor yang memadai. Adapun kesimpulan dari penelitian ini yakni diperoleh persamaan regresi sederhana sebagai berikut : $Y=7,089+$ $0,913 \mathrm{X}$. Persamaan regresi menunjukkan bahwa jika lingkungan kerja konstan atau $\mathrm{X}=0$, maka kinerja pegawai sebesar 7,089, kemudian koefisien determinasi $\left(R^{2}\right)=0,834$. Hal ini menunjukkan bahwa sebesar 83,40\% kinerja pegawai dapat dijelaskan oleh variabel lingkungan kerja, sedangkan sisanya $(100 \%-83,40 \%=16,60 \%)$ dijelaskan atau dipengaruhi oleh faktor-faktor lain yang tidak diteliti. Karena taraf nyata á $(0,05)>$ Significancy $(0,000)$ maka $\mathrm{H}_{0}$ ditolak, artinya ada pengaruh secara signifikan dan simultan antara variabel lingkungan kerja dengan kinerja. Jadi dapat disimpulkan bahwa lingkungan kerja berpengaruh signifikan terhadap kinerja pegawai pada Bank Riau Kepri Syariah Pekanbaru.
\end{abstract}

Kata Kunci : Lingkungan Kerja, Kinerja 


\section{PENDAHULUAN}

Setiap organisasi pemerintah dituntut untuk dapat mengoptimalkan sumber daya manusia dan bagaimana sumber daya manusia itu dikelola. Pengelolaan sumber daya manusia tidak lepas dari faktor pegawai yang diharapkan dapat sebaik mungkin demi mencapai tujuan organisasi pemerintah. Pegawai merupakan asset utama organisasi dan mempunyai peran yang strategis didalam organisasi yaitu sebagai pemikir, perencana, dan pengendali aktivitas organisasi.

Manusia memerlukan organisasi dan juga sebaliknya organisasi memerlukan manusia untuk menjalankan kegiatannya. Sukses atau tidaknya organisasi tersebut tergantung pada kualitas sumberdaya manusia yang dimiliki organisasi tersebut. Manusia merupakan faktor utama dalam mewujudkan eksistensi organisasi. Keterlibatan manusia dalam proses pelaksanaan kegiatan organisasi biasanya diwujudkan dalam hubungan yang bersifat formal.

Lingkungan kerja dalam suatu instansi pemerintahan sangat penting untuk diperhatikan dan mempunyai pengaruh langsung terhadap kinerja pegawai atau pegawai yang melaksanakan tugasnya. Suatu kondisi lingkungan kerja dikatakan baik atau sesuai apabila manusia dapat melaksanakan kegiatan secara optimal, sehat, aman dan nyaman. Kesesuaian lingkungan kerja dapat dilihat akibatnya dalam jangka waktu panjang yang lama. Lingkungan kerja yang kurang baik atau boleh dikatakan buruk akan mempengaruhi mental dan psikis seseorang. Dalam hal ini sumber daya manusianya yang akan menyebabkan turunnya kinerja pegawai yang tentunya akan merugikan instansi/perusahaan.
Karena lingkungan kerja merupakan salah satu faktor yang dapat mempengaruhi kinerja pegawai, maka sudah selayaknya dikelola dengan sebaik-baiknya sehingga dapat memotivasi para pegawai dan membantu kelancaran dalam pelaksanaan aktifitas pegawai. Lingkungan kerja yang di kelola dengan baik akan memberi kenyamanan dan kesajahteraan kerja bagi para pegawai dalam melaksanakan aktifitasnya, sehingga akan mendukung dalam pencapaian tingkat kinerja. Disamping itu, jika hubungan kerja dan kebijaksanaan yang diterapkan kurang memberikan kesempatan untuk pengembangan karir dan partisipasi kerja, maka akan berdampak rendahnya motivasi kerja. Hal ini pada akhirnya akan mempengaruhi pula pada tingkat kinerja pegawai.

Pada dasarnya lingkungan kerja terbagi dua yaitu lingkungan kerja fisik dan non fisik. Secara garis besar lingkungan kerja fisik terbagi atas dua kelompok yaitu kelompok pertama adalah direncanakannya berbagai macam fasilitas untuk pelayanan pegawai. Fasilitas-fasilitas ini ada beberapa macam antara lain pengadaan kamar mandi,mushala dan tempat peristirahatan.

Kelompok kedua adalah masalah kondisi kerja. Pengaturan kondisi kerja yang baik akan menaikkan tingkat kinerja yang tinggi atau baik. Dalam pengaturan kondisi kerja ini termasuk antara lain pengaturan penerangan ruangan kerja, pengaturan suhu udara, pengaturan suara, ruang gerak yang diperlukan serta keamanan pegawai.

Secara garis besar yang termasuk dalam lingkungan kerja non fisik adalah hubungan kerja dalam instansi. Hubungan pegawai ini juga akan ikut menentukan tingkat kinerja dari pegawai tersebut. Hubungan pegawai yang tidak serasi akan 
menurunkan kinerja para pegawai. Hal ini disebabkan karna didalam penyelesaian tugas-tugasnya para pegawai akan merasa terganggu atau diganggu dengan hal-hal lain sebagai akibat dari tidak serasinya hubungan pegawai yang ada didalam perusahaan tersebut.

Berikut ini data hasil rekapitulasi jumlah nasabah Bank Riau Kepri Syariah Pekanbaru :

Tabel 1 : Rekapitulasi Tahunan Nasabah Bank Riau Kepri Syariah Pekanbaru

\begin{tabular}{|l|c|c|c|c|c|}
\hline \multirow{2}{*}{\multicolumn{1}{c|}{ BULAN }} & \multicolumn{5}{|c|}{ TAHUN } \\
\cline { 2 - 6 } & $\mathbf{2 0 1 4}$ & $\mathbf{2 0 1 5}$ & $\mathbf{2 0 1 6}$ & $\mathbf{2 0 1 7}$ & $\mathbf{2 0 1 8}$ \\
\hline Januari & 968 & 1002 & 923 & 936 & 816 \\
\hline Februari & 1088 & 1037 & 1004 & 801 & 869 \\
\hline Maret & 989 & 1050 & 1009 & 840 & 1024 \\
\hline April & 871 & 1222 & 1138 & 846 & 1032 \\
\hline Mei & 1038 & 1230 & 986 & 903 & 1028 \\
\hline Juni & 987 & 1299 & 1047 & 930 & 928 \\
\hline Juli & 1165 & 1319 & 1075 & 1002 & 703 \\
\hline Agustus & 1222 & 1424 & 1402 & 1186 & 580 \\
\hline September & 1243 & 1729 & 1105 & 927 & 905 \\
\hline Oktober & 1673 & 1499 & 1008 & 801 & 721 \\
\hline November & 1110 & 1298 & 1001 & 715 & 474 \\
\hline Desember & 1324 & 1237 & 934 & 943 & 325 \\
\hline Jumlah & $\mathbf{1 2 . 3 7 2}$ & $\mathbf{1 5 . 3 4 6}$ & $\mathbf{1 2 . 6 3 2}$ & $\mathbf{1 0 . 8 3 0}$ & $\mathbf{9 . 4 0 5}$ \\
\hline
\end{tabular}

Sumber : Bank Riau Kepri Syariah Pekanbaru

Berikut ini dapat dilihat data mengenai pegawai Bank Riau Kepri Syariah Pekanbaru :

Tabel 2 : Data Jumlah Pegawai Bank Riau Kepri Syariah Pekanbaru Pekanbaru

\begin{tabular}{|c|l|c|c|}
\hline No & \multicolumn{1}{|c|}{ Posisi pegawai } & Jumlah Pegawai & Pendidikan \\
\hline 1 & Pegawai Tetap & 26 orang & S2 + S1 + SMA \\
\hline 2 & Pegawai Tidak tetap & 9 orang & S1 + SMA + SLTP \\
\hline & Jumlah & 35 orang & \\
\hline
\end{tabular}

Sumber : Bank Riau Kepri Syariah Pekanbaru

Dari data diatas maka kita dapat ketahui bahwa jumlah pegawai tetap dan tidak tetap pada Bank Riau Kepri Syariah Pekanbaru adalah 35 orang dengan latar belakang S2 , S1, SMA, SLTP yang bertugas berbeda-beda. Dari hasil pengamatan penulis, lingkungan kerja pada Bank Riau Kepri Syariah Pekanbaru dapat dilihat dari ruangan kerja yang bersih dan nyaman, kerja sama antara pegawai serta fasilitas kantor yang memadai.

\section{TINJAUAN PUSTAKA}

\section{Pengertian Lingkungan Kerja}

Lingkungan kerja di dalam instansi sangat penting untuk diperhatikan oleh 
manajemen instansi yang akan mendirikan pabrik untuk instansi tersebut. Lingkungan kerja yang baik akan mengakibatkan naiknya produktivitas kerja pegawai di dalam suatu instansi. Lingkungan kerja yang cukup memuaskan di mana para pegawai merasa nyaman dan aman akan mendorong para pegawai tersebut untuk bekerja dengan sebaik-baiknya. Menurut Nitisemito (2006:183) mendefinisikan lingkungan kerja adalah segala sesuatu yang ada disekitar para pekerja yang dapat mempengaruhi dirinya dalam menjalankan tugas-tugas yang diembankan. Sedangkan Menurut Tohardi (2004:142), lingkungan kerja fisik adalah keseluruhan atau setiap aspek dari gejala fisik dan sosial-kultural yang mengelilingi atau mempengaruhi individu.

Lingkungan kerja juga diartikan segala sesuatu yang ada di sekitar para pekerja yang dapat mempengaruhi dirinya dalam menjalankan tugas-tugas yang dibebankan, misalnya penerangan, suhu udara, ruang gerak, keamanan, kebersihan, musik dan lain-lain. (Siagian, 2003:90).

Berdasarkan definisi tersebut dapat dinyatakan lingkungan kerja fisik adalah segala sesuatu yang ada di sekitar pegawai bekerja yang mempengaruhi pegawai dalam melaksanakan beban tugasnya. Masalah lingkungan kerja dalam suatu organisasi sangatlah penting, dalam hal ini diperlukan adanya pengaturan maupun penataan faktor-faktor lingkungan kerja fisik dalam penyelenggaraan aktivitas organisasi Sedarmayati mendefinisikan lingkungan kerja sebagai berikut:

Menurut Sedarmayanti (2001:5), lingkungan kerja adalah keseluruhan alat perkakas dan bahan yang dihadapi, lingkungan sekitarnya di mana seseorang bekerja, metode kerjanya, serta pengaturan kerjanya baik sebagai perseorangan maupun sebagai kelompok.
Dari beberapa pendapat di atas, disimpulkan bahwa lingkungan kerja sebagai sumber informasi dan tempat melakukan aktifitas, maka kodisi lingkungan kerja yang baik harus dicapai agar pegawai merasa betah dan nyaman di dalam ruangan untuk menyelesaikan pekerjaan sehingga dapat efisiensi yang tinggi. Lingkungan kerja yang baik akan membawa dampak pada meningkatnya kualitas pekerjaan, mengurangi ketenangan pada mata dan keinginan rohaniah, serta yang terpenting semangat kerja lebih baik dan prestise yang lebih baik untuk instansi yang bersangkutan.

\section{Pengertian Kinerja}

Semakin berkembangnya organisasi maka semakin banyak pula melibatkan tenaga kerja dalam usaha menunjang kelancaran jalannya organisasi disamping memperhatikan faktor-faktor produksi lainnya. Jika kita berbicara mengenai produk/jasa yang dihasilkan oleh suatu organisasi maka hal tersebut tidak akan terlepas dari permasalahan kinerja (Arif, 2018).

Pengertian kinerja menurut Stephen P. Robbin (2006:82) adalah jawaban atas pertanyaan "apa yang dicapai seseorang sesudah mengerjakan sesuatu”. Selanjutnya pengertian kinerja menurut Manullang (2004:103) adalah "Suatu keadaan yang menunjukkan banyaknya pekerjaan yang harus dilakukan atau dihasilkan seorang individu atau kelompok kerja sesuai dengan job description mereka masingmasing

Menurut Anwar Prabu Mangkunegara (2006:160) kinerja adalah hasil kerja secara kualitas dan kuantitas yang dicapai oleh seseorang pegawai dalam melaksanakan tugasnya dengan tanggung jawab yang diberikan kepadanya.

Menurut Siagian (2005:53), manusia tidak tergeser oleh perkembangan dan 
pemanfaatan teknologi, meskipun benar timbul tantangan baru dalam arti bahwa tenaga kerja yang pekerjaan diambil alih oleh mesin sangat mungkin harus mengalami pendidikan dan pelatihan tambahan dituntut oleh tugas baru yang dipercayakan kepadanya.

\section{Faktor-faktor yang Mempengaruhi Kinerja Pegawai}

Untuk mengetahui faktor yang mempengaruhi kinerja individu, perlu dilakukan pengkajian terhadap teori kinerja. Secara umum faktor non fisik dan fisik sangat mempengaruhi. Berbagai kondisi lingkungan fisik sangat berpengaruh kondisi dalam pegawai dalam bekerja. Selain itu, kondisi lingkungan fisik juga akan mempengaruhi berfungsinya faktor lingkungan non fisik. Pada kesempatan ini pembahasan kita fokuskan pada lingkungan non fisik, yaitu kondisikondisi yang sebenarnya sangat melekat dengan system manajerial instansi. Menurut Handoko (2008:82), faktor-faktor yang mempengaruhi kinerja adalah :

a. Keterampilan atau Pengalaman. Orang yang mempunyai pendidikan yang rendah jelas mempunyai keterampilan yang kurang, begitu juga orang yang sudah agak tinggi masih tetap mempunyai produktivitas yang rendah. Oleh sebab itu, maka diperlukan adanya keterpaduan antara keterampilan dengan pengalaman kerja. Orang atau tenaga kerja yang masih muda baru mulai mengikuti karier, biasanya bekerja agak kurang pengalaman, hal ini dapat diatasi dengan cara mengikuti pelatihan kerja diluar atau pada tempat kerja untuk meningkatkan keterampilan.

b. Faktor Pendidikan. Instansi perindustrian biasanya direkrut dari orang-orang yang kurang mempunyai pendidikan yang tinggi, instansi hanya membutuhkan kesehatan fisik yang kuat untuk bekerja. Dengan adanya pendidikan yang kurang dari pekerja akan menyebabkan produktivitasnya.

c. Umur. Umur seorang tenaga kerja agaknya akan dapat dijadikan sebagai tolak ukur dari produktivitasnya, akan tetapi hal tersebut tidak selalu begitu. Tetapi pengejaran karir seseorang selalu diimbangi dengan jumlah umur, dimana semakin bertamabah lama orang itu bekerja, maka produktivitas dari orang tersebut akan meningkat.

d. Sarana Penunjang. Tingkat kemampuan untuk membutuhkan motivasi kerja antara pekerja serta mengadakan pembagian kerja yang jelas antara semua pegawai sangat berpengaruh terhadap tingkat produktivitas. Disamping itu dapat juga berupa penerapan teknologi sarana produksi yang cukup canggih, hal ini menyebabkan tugas atau kerja dari pegawai tersebut berkurang.

e. Faktor Semangat dan Kegairahan Kerja. Dengan adanya dorongan moril terhadap para pekerja akan meningkatkan produktivitas kerja. Dorongan moril tersebut berupa memberikan semangat dan kegairahan kerja kepada para pekerja. Seperti yang dikemukan oleh pakar manajemen, semangat dan kegairahan kerja merupakan problematic yang harus mendapat perhatian serius.

f. Faktor Motivasi. Faktor motivasi adalah suatu dorongan dalam diri pegawai untuk melakukan suatu kegiatan atau tugas dengan sebaik-baiknya agar mampu mencapai kinerja dengan predikta yang bagus

Hubungan antara Lingkungan Kerja dengan Kinerja Pegawai

Banyak faktor yang dapat meningkatkan kinerja pegawai diantaranya 
menciptakan lingkungan kerja yang kondusif, displin kerja yang tinggi dan lain sebagainya. Lingkungan kerja yang kondusif meliputi ukuran ruang kerja, penerangan, suhu udara, warna, kebersihan tempat kerja dan tersedianya peralatan kerja. Jika lingkungan kerja tidak kondusif akan mengakibatkan stress bagi pegawai yang pada akhirnya akan menimbulkan penurun kinerja pegawai.

Lingkungan kerja pegawai sebagai salah satu faktor yang dapat mempengaruhi produktifitas kerja tentunya perlu dikelola dengan sebaik-baiknya sehingga dapat memotivasi para pegawai dan membantu kelancaran dalam pelaksanaan aktiitas pegawai. Oleh sebab itu selain faktor lingkungan kerja yang erat hubungannya dalam mempengaruhi kepuasan kerja. Dalam melaksanakan pekerjaan lingkungan ini kerja sangat mempengaruhi dan memegang peran penting karena berhubungan dekat dengan pegawai dalam melakukan pekerjaan, dan secara umum dapat diartikan bahwa lingkungan kerja adalah segala sesuatu yang berada disekitar para pekerja yang mempengaruhi dalam melakukan pekerjaan yang dibebankan kepadanya oleh instansi baik secara langsung maupun secara tidak langsung.

\section{Penilaian Kinerja Pegawai}

Penelian kinerja (performance apparaisal) pada dasar nya merupakan faktor kunci guna mengembangkan suatu organisasi secara efektif dan efisien, karena adanya kebijakan atau program yang lebih baik atau sumber daya manusia yang ada dalam organisasi. Penilaian kinerja individu sangat bermanfaat bagi dinamika pertumbuhan organisasi secara keseluruhan, melalui penilaian tersebut maka dapat diketahui kondisi sebenarnya tentang bagaimana kinerja pegawai (Arif, 2019).
Kinerja pegawai perlu diperhatikan guna mempertahankan dan meningkatkan kepuasaan pelanggan. Dampak penilaian kinerja individu pegawai mamiliki imbas negative maupun positif terhadap moral kerja pegawai. Pada saat penilaianpenilaian kinerja dipakai untuk disiplin, kenaikan gaji, promosi pemecatan atau pemberhentian sementara, maka penilaian kinerja dianggap paling menakutkan oleh orang-orang yang menganggap kemampuan dirinya rendah.

\section{METODE}

\section{Jenis Dan Sumber Data}

Adapun jenis data yang penulis kumpulkan dalam penulisan skripsi ini adalah :

1. Data Primer. Data Primer yaitu data yang diperoleh langsung dari responden dengan cara kuisioner dan pengamatan langsung tentang pengaruh lingkungan kerja terhadap kinerja pegawai.

2. Data Skunder. Data Skunder yaitu data yang berasal dari laporanlaporan maupun literature yang dibutuhkan dalam penelitian ini.

\section{Populasi Dan Sampel}

Populasi adalah kumpulan atau agregasi dari seluruh elemen-elemen atau individu-individu yang merupakan sumber informasi dalam suatu penelitian (Bonar M. Sinaga, 1994). Sebagai populasi dalam penelitian ini adalah seluruh pegawai yang bekerja pada Bank Riau Kepri Syariah Pekanbaru 2014-2018.

Sampel adalah sebagian dari seluruh elemen-elemen atau individu-individu yang terdapat pada populasi. Dalam Penelitian ini seluruh karyawan administratif dalam populasi sebagai anggota sampel. Ukuran sampel sebanyak orang tersebut sudah memenuhi saran Hair et al. (1995), mengenai sampel yang representatif 
untuk digunakan dalam teknik analisis SPSS.

\section{Teknik Pengumpulan Data}

Adapun metode yang digunakan penulis dalam usaha pengumpulan data adalah sebagai berikut :

1. Wawancara (Interview). Adalah metode pengumpulan data dimana penulis melakukan wawancara secara langsung dengan pihak yang berkaitan langsung dengan objek penelitian.

2. Menyusun Daftar Pertanyaan (Kuisioner). Adalah metode pengumpulan data dimana dalam hal ini penulis membuat suatu daftar pertanyaan yang nantinya akan diberikan kepada para pegawai yang menjadi responden untuk mendapatkan data lapangan yang dibutuhkan oleh penulis dalam menyelesaikan penelitian ini.

\section{Analisis Data}

Analisis data dalam penelitian ini menggunakan metode deskriptif kuantitatif yaitu menganalisa data dengan cara merumuskannya berdasarkan landasan teori yang erat hubungannya dengan masalah yang dibahas selanjutnya dari hasil analisa tersebut diukur dengan menggunaakan analisa kuantitatif, kemudian diambil beberappa kesimpulan dan diakhiri dengan mengemukakan saran yang dianggap perlu. Kemudian dilanjutkan dengan analisis kuantitatif menggunakan analisis regresi linear sederhana, yaitu sebagai berikut :

a. Menentukan model persamaan regresi linear sederhana

Analisis regresi linear sederhana ini bertujuan untuk melihat pengaruh antara pengaruh lingkungan kerja dengan kinerja pegawai. Persamaan regresinya adalah sebagai berikut :
Dimana :

$$
\mathrm{Y}=\mathrm{a}+\mathrm{bX}+\varepsilon
$$

$\mathrm{Y}=$ Kinerja kerja pegawai

$\mathrm{a}=$ Konstanta

$\mathrm{b}=$ Koefesien regresi

$\mathrm{X}=$ Lingkungan kerja pegawai

$\varepsilon=$ Episilon (Variabel yang

mempengaruhi $=\sqrt{1-R} 2$ )

Untuk mencari nilai a dan $b$

digunakan rumus sebagai berikut:

$$
\begin{aligned}
& b=\frac{n \sum \mathbf{x y}-\Sigma \mathbf{x} \sum \mathbf{y}}{\left.n \sum \mathbf{x}^{2}-(\Sigma \mathbf{x})\right]^{2}} \\
& a=\bar{Y}-b \bar{X}
\end{aligned}
$$

b. Menentukan koefisien korelasi (r) Untuk melihat kuat lemahnya pengaruh antara variable lingkungan kerja terhadap kinerja pegawai maka digunakan analisa korelasi dengan rumus-rumus :

$$
r=\frac{n \sum \mathbf{X Y}-\left(\sum \mathbf{X}\right)\left(\sum \mathbf{Y}\right)}{\sqrt{\left[n \sum \mathbf{X}^{2}-\left(\sum[\mathbf{X})\right]^{2}\right]\left[n \sum \mathbf{Y}^{2}-\left(\sum[\mathbf{Y})\right]^{2}\right]}}
$$

Dimana :

$\mathrm{r}=$ Koefesien korelasi

$\mathrm{n}=$ Jumlah sampel

c. Menentukan koefesien Determinasi $\left(R^{2}\right)$

Koefesien determinasi $\left(\mathrm{R}^{2}\right)$ merupakan angka yang menunjukkan seberapa besar perubahan variabel tak bebas (Y) dapat dipengaruhi oleh variabel bebas $(\mathrm{X})$, yang dihitung dengan rumus :

$$
R^{2}=\frac{b\{n \Sigma \mathbf{X Y}-(\Sigma \mathbf{X})(\Sigma \mathbf{Y})\}}{\left.n \Sigma^{\mathbf{Y}^{2}}-(\Sigma \mathbf{Y} \mathbf{Y})\right]^{2}}
$$

Variabel $\mathrm{X}$ dan $\mathrm{Y}$ yang digunakan dalam analisis regresi linier ini diperoleh dari hali kuisioner tentang masing-masing variabel tersebut. Untuk mengubah data kualitatif hasil kuisioner menjadi data 
kuantitatif yang dibutuhkan dalam analisis regresi linier tersebut, maka digunakan skala ordinal sebagai berikut :

1) Variabel $X$ (Lingkungan kerja)

- Sangat Memuaskan : Bobot/ nilai $=5$

- Memuaskan: Bobot/ nilai $=4$

- Cukup : Bobot/ nilai = 3

- Kurang Memuaskan : Bobot/ nilai $=2$

- Sangat Kurang Memuaskan : Bobot $/$ nilai $=1$

2) Variabel Y (Kinerja Pegawai)

- Sangat Memuaskan : Bobot/ nilai $=5$

Tabel 3 : Analisis Regresi Sederhana

Coefficients $^{\mathrm{a}}$

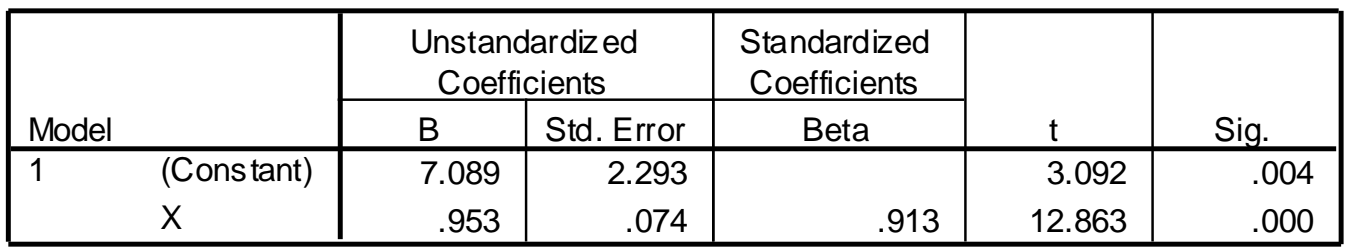

a. Dependent Variable: $Y$

Sumber : Hasil Perhitungan Data SPSS

Berdasarkan tabel diatas, yang diperoleh dari hasil pengolahan dan komputerisasi dengan menggunakan program SPSS maka diperoleh persamaan regresi sederhana sebagai berikut : $\mathrm{Y}=$ 7,089+0,913 X.

Persamaan regresi di atas dapat dijelaskan sebagai berikut :

$\mathrm{a}=7,089$ menunjukkan bahwa jika lingkungan kerja konstan atau $\mathrm{X}$ $=0$, maka kinerja pegawai sebesar 7,089.

\section{PEMBAHASAN}

Analisis Regresi Sederhana
- Memuaskan : Bobot/ nilai $=4$

- Cukup : Bobot/ nilai = 3

- Kurang Memuaskan : Bobot/ nilai $=2$

- Sangat Kurang Memuaskan : Bobot $/$ nilai $=1$ 
Tabel 4 : Koefisien Determinasi

Model Summary

\begin{tabular}{|l|r|r|r|r|}
\hline Model & R & R Square & $\begin{array}{c}\text { Adjusted } \\
\text { R Square }\end{array}$ & $\begin{array}{c}\text { Std. Error of } \\
\text { the Estimate }\end{array}$ \\
\hline 1 & $.913^{\mathrm{a}}$ & .834 & .829 & 1.06891 \\
\hline
\end{tabular}

a. Predictors: (Cons tant), $X$

b. Dependent Variable: $Y$

Sumber : Hasil Perhitungan Data SPSS

Dari hasil pengolahan data variabel lingkungan kerja, sedangkan komputerisasi dengan menggunakan sisanya $(100 \%-83,40 \%=16,60 \%)$ program SPSS maka diperoleh koefisien dijelaskan atau dipengaruhi oleh faktordeterminasi $\left(\mathrm{R}^{2}\right)=0,834$. Hal ini faktor lain yang tidak diteliti. menunjukkan bahwa sebesar $83,40 \%$ kinerja pegawai dapat dijelaskan oleh Uji F

Tabel 5 : Koefisien Determinasi

ANOVA

\begin{tabular}{|ll|r|r|r|r|r|}
\hline Model & & \multicolumn{1}{|c|}{$\begin{array}{c}\text { Sum of } \\
\text { Squares }\end{array}$} & df & Mean Square & \multicolumn{1}{c|}{$\mathrm{F}$} & Sig. \\
\hline 1 & Regression & 189.038 & 1 & 189.038 & 165.449 & $.000^{\mathrm{a}}$ \\
& Residual & 37.705 & 33 & 1.143 & & \\
& Total & 226.743 & 34 & & & \\
\hline
\end{tabular}

a. Predictors: (Constant), $\mathrm{X}$

b. Dependent Variable: $Y$

Sumber : Hasil perhitungan data SPSS

1. Membuat formula hipotesis

a. $\mathrm{H}_{0}$ : Tidak ada pengaruh yang signifikan antara variable lingkungan kerja dengan kinerja.

b. $\mathrm{H}_{1}$ : Ada pengaruh yang signifikan antara variabel variable lingkungan kerja dengan kinerja.

2. Menentukan taraf nyata (á). Taraf nyata yang digunakan adalah $5 \%(0,05)$

3. Menentukan kriteria pengujian

a. $\mathrm{H}_{0}$ diterima ( $\mathrm{H}_{1}$ ditolak) apabila

Taraf nyata á $(0,05) \leq$ Significancy

b. $\mathrm{H}_{0}$ ditolak ( $\mathrm{H}_{1}$ diterima $)$ apabila

Taraf nyata á $(0,05)>$ Significancy
Karena taraf nyata á $(0,05)>$ Significancy $(0,000)$ maka $\mathrm{H}_{0}$ ditolak, artinya ada pengaruh secara signifikan dan simultan antara variabel lingkungan kerja dengan kinerja. Jadi dapat disimpulkan bahwa lingkungan kerja berpengaruh signifikan terhadap kinerja pegawai pada Bank Riau Kepri Syariah Pekanbaru.

\section{Uji t (t-test)}

Uji-t digunakan untuk mengetahui pengaruh variabel bebas terhadap variabel terikat secara individual dengan mengukur hubungan antara variabel bebas dengan variabel terikat.

4. Kesimpulan 


\section{Tabel 6 : Signifikasi uji parsial/T-hitung}

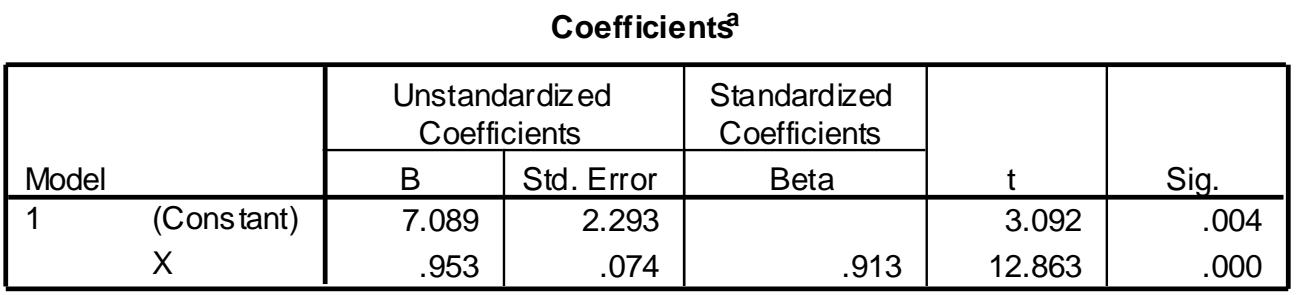

a. Dependent Variable: $Y$

Sumber : Hasil perhitungan data SPSS

1. Membuat formula hipotesis

$\mathrm{H}_{0}$ : Tidak ada pengaruh yang signifikan antara variable lingkungan kerja dengan kinerja.

$\mathrm{H}_{1}$ : Ada pengaruh yang signifikan antara variabel variable lingkungan kerja dengan kinerja.

2. Menentukan taraf nyata (á). Taraf nyata yang digunakan adalah $5 \%(0,05)$

3. Menentukan kriteria pengujian $\mathrm{H}_{0}$ diterima ( $\mathrm{H}_{1}$ ditolak) apabila Taraf nyata á $(0,05) \leq$ Significancy

$\mathrm{H}_{0}$ ditolak $\left(\mathrm{H}_{1}\right.$ diterima $)$ apabila Taraf nyata á $(0,05)>$ Significancy

4. Kesimpulan

Karena taraf nyata á $(0,05)>$ Significancy $(0,000)$ maka $\mathrm{H}_{0}$ ditolak, artinya ada pengaruh secara signifikan antara variabel lingkungan kerja dengan kinerja. Jadi dapat disimpulkan bahwa lingkungan kerja berpengaruh signifikan terhadap kinerja pegawai pada Bank Riau Kepri Syariah Pekanbaru.

\section{SIMPULAN}

1. Diperoleh persamaan regresi sederhana sebagai berikut : $Y=7,089+$ $0,913 \quad X . \quad$ Persamaan regresi menunjukkan bahwa jika lingkungan kerja konstan atau $\mathrm{X}=0$, maka kinerja pegawai sebesar 7,089 .
2. Diperoleh koefisien determinasi $\left(\mathrm{R}^{2}\right)=$ 0,834 . Hal ini menunjukkan bahwa sebesar $83,40 \%$ kinerja pegawai dapat dijelaskan oleh variabel lingkungan kerja, sedangkan sisanya $(100 \%$ $83,40 \%=16,60 \%$ ) dijelaskan atau dipengaruhi oleh faktor-faktor lain yang tidak diteliti.

3. Karena taraf nyata á $(0,05)>$ Significancy $(0,000)$ maka Ho ditolak, artinya ada pengaruh secara signifikan dan simultan antara variabel lingkungan kerja dengan kinerja. Jadi dapat disimpulkan bahwa lingkungan kerja berpengaruh signifikan terhadap kinerja pegawai pada Bank Riau Kepri Syariah Pekanbaru.

4. Uji-t digunakan untuk mengetahui pengaruh variabel bebas terhadap variabel terikat secara individual dengan mengukur hubungan antara variabel bebas dengan variabel terikat. Karena taraf nyata á $(0,05)>$ Significancy $(0,000)$ maka $\mathrm{H}_{0}$ ditolak, artinya ada pengaruh secara signifikan antara variabel lingkungan kerja dengan kinerja. Jadi dapat disimpulkan bahwa lingkungan kerja berpengaruh signifikan terhadap kinerja pegawai pada Bank Riau Kepri Syariah Pekanbaru. 


\section{DAFTAR RUJUKAN}

Arif, M., \& Ardiyan, B. (2019). Analisis Faktor Penempatan Jabatan terhadap Prestasi Kerja Karyawan pada PT. Zaman Teknindo Pekanbaru. COSTING: Journal of Economic, Business and Accounting, 2(2), 302-314.

Arif, M. (2018). Analisis Rekrutmen dan Penempatan Kerja terhadap Kinerja Karyawan pada Hotel Oase. Al-Hikmah: Jurnal Agama Dan Ilmu Pengetahuan, 15(1), 42-63.

Dessler, Gary. (2001). Manajemen Sumber Daya Manusia Jilid 2. PT. Prehalindo, Jakarta.

Handoko, T, Hani. (2002). Manajemen Edisi ke dua. BPEE, Yogyakarta.

Hasibuan H. Malayu S.P. (2003). Manajemen

Sumber Daya Manusia. Bumi Aksara, Jakarta.

Heidjarachman, Ranupandojo. dan Suad Husnan. (2001). Manajemen Personalia, edisi keempat. BPFE, Yogyakarta.

Kusriyanto, Bambang. Meningkatkan Pegawai. Pustaka Binaman Presindo, Jakarta.

Mangkunegara, P.Anwar. A. A. (2000). Manajemen Sumber Daya Manusia. PT Remaja Rosdakarya, Bandung.

Marzuki. (2003). Metodologi Riset. Penerbit BPFE Universitas Islam Indonesia, Yogyakarta.

Moekijat. (2003). Manajemen Tenaga Kerja dan Hubungan Kerja. Pionir, Bandung.

Nitisemito, Alex S. (2002). Manajemen Personalia. Ghalia Indonesia, Jakarta.

Nur Fitriyaningsih, Ubungan. (2008). Antara Lingkungan Kerja Dengan Produktivitas Kerja Pegawai.
Universitas Muhammadiyah, Surakarta.

Pamudji, S. (2004). Kepemimpinan Pemerintah di Indonesia. Bumi Aksara, Jakarta.

Riyanto, A. (2001). Sistem Manajemen Kerja. Gramedia, Jakarta.

Sedarmayanti. (2001). Sumber Daya Manusia dan Produktivitas Kerja. Bandung.

Sinungan, Muchdarsyah. (2003). Produktivitas, Apa dan Bagaimana. Bumi Aksara, Jakarta.

Sondang, P. Siagian. (2003). Manajemen Sumber Daya Manusia. Penerbit Bumi Aksara, Jakarta.

Tulus, Muhammad Agus. (2000). Manajemen Sumber Daya Manusia. PT. Gramedia Pustaka Utama, Jakarta. 